WPA forums in psychiatry

The following are available via the publication section of the WPA website (www.wpanet.org):

O The Declaration of Madrid and Current Psychiatric Practice: Users' and Advocates' Views

o Psychiatrists and the Death Penalty: Some Ethical Dilemmas

O Psychiatry in M edical Education

- Managed Care and Psychiatry

o Culture, Spirituality and Psychiatry

- Mass M edia and Psychiatry

o Psychiatry and H uman Sexuality.

\section{Eating disorders}

A sixth volume in the W PA's very successful series 'Evidence and Experience in Psychiatry' has been published, entitled Eating Disorders (eds M. Maj, K. H almi, J. J. LópezIbor \& N . Sartorius. Chichester: W iley, 2003). Worldwide, eating disorders may be one of the major areas of clinical psychiatry in which the gap between research evidence and clinical practice is most dramatic. The six chapters deal with diagnosis, epidemiology, physical complications, pharmacological treatment, psychological interventions and social/economic burden. Each consists of a systematic review of the research evidence, followed by many commentaries from virtually all the renowned experts in the field.

\section{Classification and diagnosis}

Work progresses towards the next revisions of the world's current classification systems. A successful major W PA International Thematic Conference took place in Vienna in June in collaboration with the Austrian Society of Psychiatry and Psychotherapy. In May, the W PA Section on Classification, in collaboration with the WHO Classification $O$ ffice, organised the Symposium on Philosophical and Methodological Foundations of Psychiatric Diagnosis in $\mathrm{N}$ ew York. A diversity of first-rate contributions, from philosophers, psychiatrists and other health scientists, addressed the complex issues. The $\mathrm{N}$ ewsletter featuring this symposium is available on the Section's website: www.wpanet.org.
The WPA Section of Affective

\section{Disorders}

The Section has adopted the Journal of Affective Disorders as its house journal. A fruitful collaboration has also been established with the International Society for Affective $D$ isorders (ISAD). Both the Section and the ISAD are chaired by Professor Chris Thompson. The ISAD had a very successful inaugural meeting in Taormina, Sicily, in March 2002. Its next meeting is in C ancun, Mexico, 5$10 \mathrm{March} 2004$. ISAD members receive a personal subscription to the Journal of Affective Disorders as part of their membership. Details of membership and of the $C$ ancun meeting can be found on the website www.isad.org.uk.

\section{Albert Schweitzer Medal}

Professor H enry Walton, Professor Emeritus of Psychiatry and of International Medical Education, U niversity of Edinburgh, has been awarded the Albert Schweitzer Grand Gold Medal of the Albert Schweitzer World Academy of Medicine. This was for humanitarian services with respect to his international medical education work over numerous decades and was presented at a ceremony in the Royal Castle of Warsaw on 15 May 2003. Professor Walton was the foundation President of the Association for Medical Education in Europe, and subsequently the longterm President of the World Federation for Medical Education. $\mathrm{He}$ initiated the G lobal Curriculum in Psychiatry programme of the World Psychiatric Association.
All psychiatrists can obtain extensive up-to-date information about international news, publications and conferences

(and much more)

by subscribing electronically to the monthly e-bulletin of the WPA. Subscriptions are available

through the website

www.wpanet.org/

\title{
Forthcoming international events
}

31 October- 2 N ovember 2003

15th $\mathrm{N}$ ational Conference of the Indian Association for Social Psychiatry

Trichy, India.

Contact: Dr Savita Malhotra.

Email: savitam@ sancharnet.in.

31 October- 3 N ovember 2003

Third International Conference on the Synthesis of Psycho-

therapy and Pharmacotherapy

Thematic conference.

Amsterdam, The $\mathrm{N}$ etherlands.

Contact: Dr Rob M. W. Smeets.

Email: mmoalem@ kenes.com.

\section{9-13 November 2003}

Psychiatric Care Across Cultures: A Conference Week WPA Section on Transcultural Psychiatry in collaboration with the U niversity of Malta.

Malta St Julian's, Republic of Malta.

Email: charles.pace@um.edu.mt; cpace_malta@ hotmail.com.

27-30 November 2003

$X I$ Congreso de la Sociedad Dominicana de Psiquiatria

WPA co-sponsored conference. In collaboration with the Latin

American Psychiatric Association.

Melia Caribe Tropical Hotel, D ominican Republic.

Contact: Dra. Daisy Acosta.

Email: daisyacosta@ codetel.net.co. 
29 January- 2 February 2004

International Conference on Schizophrenia

WPA co-sponsored conference. Schizophrenia Research Foundation (SCARF) in collaboration with the WHO.

Chennai (O ld Madras), India.

Contact: Dr R. Thara.

Email: scarf@vsnl.com.

Website: www.scarfindia.org.

\section{1-28 February 2004}

Fifth Virtual Congress of Psychiatry (interpsiquis 2004)

Palma de Mallorca, Spain

Contact: Dr Pedro Moreno.

Email: secretaria@psiquiatria.com.

Website: www.interpsiquis.com/2004/particiption.html.

5-10 March 2004

Second Biennial Conference of the International Society for Affective Disorders (ISAD)

WPA co-sponsored conference in collaboration with the WPA Section on Affective Disorders.

Cancun, Mexico.

Contact: David Beck.

Email: d.k.beck@ soton.ac.uk.

Website: www.isad.org.uk.

\section{7-20 March 2004}

Second World Congress on Women's Mental Health

WPA Section on Women's Mental Health and the WPA Section on Interdisciplinary Collaboration.

Washington, DC, USA.

Contact: Dr Donna Stewart; Dr U riel Halbreich.

Email: donna.stewart@uhn.on.ca; urielh@ acsu.buffalo.edu.

Website: www.womenmentalhealth.com.

29 March-2 April 2004

Congreso Panamericano de Salud Mental Infanto-Juvenil $O$ rganised by the Cuban Society of Psychiatry in collaboration with the WHO and the Latin American Psychiatric Association.

Palacio de Convenciones, Havana, Cuba.

Contact: Dr Cristobal Martinez Gomez.

Email: crisma@ informed.sld.cu.

Website: www.sld.cu/eventos/psiquiatria/felices;

www. lo seventos.cu/saludmental2004.

\section{4-18 April 2004}

European Psychiatry: Evidence and Experience. 12th AEP Congress

Geneva, Switzerland.

Call for absracts ends 300 ctober 2003.

Email: aep12@ kenes.com.

Website: www.kenes.com/aep2004.

1- 6 May 2004

American Psychiatric Association Annual Congress

N ew York, USA.

Contact: apa@psych.org.

Website: www.psych.org.

14- 19 May 2004

$\mathrm{H}$ istory of Psychiatry: 18th Congress of the Hellenic Psychiatric Association

In collaboration with WPA Sections on History of Psychiatry and Humanities in Psychiatry.

Island of Kos, Greece.

Contact: Prof. George Christodoulou, Hellenic Psychiatric Association, 11, Papadiamandopoulou str., 11528 Athens, Greece.

Fax: + 302107242032

Email: gnchrist@ compulink.gr.

10-13 June 2004

$\mathrm{N}$ ational Conference of the Czech Psychiatric Society

Spindleruv Mlyn, Czech Republic.

Contact: Dr Jiri Raboch.

Email: raboch@ beba.cesnet.cz.

6- 9 July 2004

Royal College of Psychiatrists Annual Meeting

International Centre, $\mathrm{H}$ arrogate, UK.

Contact: College Conference 0 ffice.

Tel: $+44(0) 2072352351 \times 142$

Fax: + 44 (0)20 72596507 .

Email: mbraithwaite@ rcpsych.ac.uk.
17-19 September 2004

WPA Regional Meeting

Mental Health Resource Center (MHRC) in collaboration with the Pakistan Psychiatric Society.

Lahore, Pakistan.

Contact: Dr Haroon Rashid Chaudry.

Email: pprc@wol.net.pk.

\section{2-26 September 2004}

14th World Congress of the World Association for Dynamic Psychiatry (W ADP)

WPA co-sponsored conference.

Cracow, Poland.

Contact: Dr Maria Ammon.

Email: wadp.congress2004@ dynpsych.de.

28 September- 1 October 2004

Translating the Evidence. International Early Psychosis Association

Vancouver, Canada.

Contact: congress@venuewest.com.

Website: www.iepa.org.au.

6-9 October 2004

8th Congress of the International Association for the Treatment of Sexual O ffenders (IATSO)

WPA co-sponsored conference.

Athens, Greece.

Contact: Dr O restis G iotakos.

Email: giotakos@ tri.forthnet.gr.

Website: ww w. iatsoathens.gr.

7-10 October 2004

Mental Health Perspectives in Public Health Conference

WPA co-sponsored conference in collaboration with the Armenian Association of Psychiatrists and $\mathrm{N}$ arcologists.

Yerevan, Armenia.

Contact: Dr Armen Soghoyan.

Email: majoria@arminco.com.

\section{4-26 October 2004}

\section{3rd World Congress on Men's Health}

WPA co-sponsored conference. International Society for Men's $\mathrm{H}$ ealth in collaboration with the International Forum of Mood and Anxiety Disorder and the Austrian Association of $\mathrm{N}$ europharmacology.

Vienna, Austria.

Contact: Dr Siegfried Kasper.

Email: sk@ akh-wien.ac.at.

Website: www.wchm.info.

\section{4-27 October 2004}

X VIII World Congress of the World Association for Social Psychiatry

The Japanese Society of Social Psychiatry in collaboration with the WHO.

Kobe, Japan.

Contact: Dr Yoshibumi N akane.

Email: yonakane@ net.nagasaki-u.ac.jp.

Website: www.congre.co.jp/18wasp.

10-13 November 2004

Treatment in Psychiatry: An Update

International Congress of the WPA.

Florence, Italy.

Contact: Prof. Mario Maj, Institute of Psychiatry, University of N aples, Largo Madonna Delle Grazie, I-80138, Italy.

Fax: + 390815666523

Email: majmario@ tin.it.

12-15 March 2005

Advances in Psychiatry and Meeting of the WPA Scientific Sections

WPA Regional Meeting.

Athens, Greece.

Contact: Prof. George Christodoulou, Athens University Department of Psychiatry, Eginition Hospital, 74, Vasilissis Sophias, 11528 Athens, Greece.

Fax: + 302107242032

Email: gnchrist@ compulink.gr. 